\title{
Milk Production with All-Grass Rations from Steep, Intensively Managed Tropical Pastures'
}

\author{
Rubén Caro Coslas and José Vicente-Chandler²
}

\section{INTRODUCTION}

Feeding of dairy cows in Puerto Rico is generally based on fairly wellmanaged pastures, mostly of Pangola grass, supplemented by 1 pound of 20 - to 24-percent protein concentrate per liter (2.2 pounds) of milk produced. About $\$ 15$ million worth (180,000 tons) of concentrated dairy feeds are imported yearly. Most dairies are located on expensive, level, or rolling lands in the Coastal Region, many of which are suited to mechanized crop production.

About 500,000 acres of land in the humid Mountain Region are suited only to pastures since they are too steep for mechanized crop production and require the protection that grass provides against erosion. Livestock production in this area can be "mechanized" by applying fertilizer and lime with broad base crawler-type tractors or aerially, while grazing cattle harvest the fornge.

Numerous long-term grazing experiments conducted in the humid Mountain Region by Vicente-Chandler et al. ${ }^{3}$ show that intensively managed pastures of improved grasses on steep slopes can carry over 2 head of growing cattle per acre and produce over 1,000 pounds of beef per acre yearly. The grazing cattle consumed about 14,000 pounds of dry matter per acre yearly containing 16 to 18 percent of crude protein. Productivity of these pastures on 50-percent slopes was only 20 percent lower than that of similarly treated pastures on level, irrigated lands. Cattle on such high-yielding pastures obtain their feed recuirements in a small area and expend little energy in walking.

1 This paper covers work carried out conperatively by the Soil and Water Conservation Research Division, Agricultural Research Service, USI)A, and the Agricultural Experiment Station, Mayagüez Campus, of the Lniversity of Puerto Rico, Río Piedras, l'.R.

Special appreciation is due to Mr. Ramón (ionzález IIernández, who provided constant encouragement, as well as the land, fertilizer, and cows for this experiment. Without his unstinting help this research would not have been possible.

2 Agronomist, cooperative hetween the Soil and Water Conservation Research Division, Agricultural Research Service, LSDA, and the Agricultural Experiment Station, Mayagiiez Campus, University of Puerto Rico, and the Project Jeader and Soil Scientist, soil and Water Conservation Research Division, ARS, USDA, Rio Piedras, P.R.

3 Vicente-Chandler, J., Caro-Costas, R., Pearson, R. W., Abruña, F., Figarella, J., and Silva, S., The Intensive Management of Tropical Fornges in Puerto Rico, 13ull. 187, Agr. lixpt. Sta., Mayagüez Campus, Univ. P.R., 152 pp., 1964. 
Little has been done to determine the productive capacity of intensively managed, heavily fertilized tropical grass pastures in terms of milk production.

The present study determined the capacity for milk production of steep, intensively managed pastures of three major tropical grasses grazed by Holstein cows receiving no concentrate feed over an 8-month lactation period.

\section{MATERIALS AND METHODS}

The experiment was carried out near Orocovis, about 2,000 feet above sea level. Average monthly temperatures range from $70^{\circ}$ to $80^{\circ} \mathrm{F}$, with

TABLE 1.-Past performance of 8 Holstein cows when fed the slandard ration currently used in Puerlo Rican dairies

\begin{tabular}{|c|c|c|c|c|c|}
\hline \multirow{2}{*}{ Cow No. } & \multirow{2}{*}{ Age } & \multirow{2}{*}{$\begin{array}{l}\text { Previous } \\
\text { lactations }\end{array}$} & \multicolumn{3}{|c|}{ Data for previous lactation } \\
\hline & & & $\begin{array}{l}\text { Total milk } \\
\text { production }\end{array}$ & $\begin{array}{l}\text { Length of } \\
\text { lactation }\end{array}$ & $\begin{array}{l}\text { Average daily } \\
\text { production }\end{array}$ \\
\hline & Years & Number & Pounds & Days & Pounds \\
\hline 503 & 8 & 5 & 4,850 & 240 & 20.2 \\
\hline 109 & 5 & 3 & 6,500 & 270 & 24.1 \\
\hline 767 & 5 & 2 & 5,320 & 210 & 25.3 \\
\hline 422 & 10 & 5 & 5,600 & 240 & 25.0 \\
\hline 263 & 5 & 3 & 6,040 & 270 & 22.4 \\
\hline 761 & 5 & 3 & 5,870 & 240 & 24.5 \\
\hline 822 & 5 & 3 & 5,970 & 300 & 19.9 \\
\hline 11 & 5 & 3 & 4,360 & 240 & 18.1 \\
\hline Average & 6.8 & 3.4 & 5,564 & 251 & $\begin{array}{c}22.2 \\
\text { (10 liters) }\end{array}$ \\
\hline
\end{tabular}

highest daily temperatures rarely exceeding $90^{\circ} \mathrm{F}$. Rainfall of about 65 inches is fairly well distributed here throughout the year. The soil is deep, red, acid, well-drained Cialitos clay on 50 -percent slopes.

Three 1-acre, 8-year-old pastures each of Pangola, Napier, and Guinea grasses, were used in this experiment. The Napier and Guinea grass pastures were cut back with machetes, to a height of about 6 inches, 2 months before starting the experiment. All pastures were provided with drinking water, shade, salt, and steamed bonemeal and received 500 pounds of 144-10 fertilizer per acre every 3 months. Soil pH was maintained at about 5.5 by periodic liming.

Information available on the experimental cows taken from a dairy herd on the South Coast of Puerto Rico, is shown in table 1. These datil show that the cows were rather poor producers. 
Over previous lactations the cows had been fed a free choice ration of good quality fresh cut grass, 4 pounds of molasses daily, and 1 pound of 24-percent protein concentrate feed per liter of milk produced.

The cows were grazed on the experimental pastures as dry cows for approximately 2 months before calving so that they would become accustomed to the new environment. Three cows were assigned at random to graze the pastures of each grass. One cow on Pangola grass developed a hoof problem with which she had been previously troubled and was removed from the experiment. Data for this cow are not included in the discussion, although she produced satisfactory yields over the first 3 months.

The three 1-acre pastures of each grass were grazed in rotation for 1week periods followed by 2 weeks of rest. The cows were on the pastures at all times and could graze at will day and night.

The cows were milked twice daily by hand and the amount of milk produced by each cow recorded. Samples for butterfat determinations were taken periodically from both the morning and evening milkings. The cows were weighed monthly.

\section{RESULTS AND DISCUSSION}

The $S$ cows on an all-tropical-grass ration from steep pastures (fig. 1) averaged 25.2 pounds or 11.5 liters of milk daily (table 2 ) during an Smonth lactation period, at the end of which the cows were still averaging 6.4 liters daily and were 4 to 6 months pregnant. The previous lactation of these cows also averaged about 8 months. The average of 11.5 liters of milk produced daily by these cows on an all-grass ration compares favorably with an average of 9 quarts per cow for class A dairies with standard feeding practices in P'uerto Rico.

Butterfat content of the milk ranged from 3.0 to 4.6 percent, averaging about 3.8 percent, slightly above average for Holsteins (table 2).

The cows produced an average of 6,064 pounds of milk on the full grass ration from steep pastures (table 2), compared to 5,564 pounds over their previous lactation on the standard ration described above.

Projections from these data show that, on a yearly basis, these pastures produced about 6,000 pounds of T.D.N. (Totally Digestible Nutrients) actually consumed by the cows. A similar projection shows that milk yields would total about 9,000 pounds per acre yearly.

The period of experimentation covers all but the two (January-February) coolest months of the year, and includes all the hot months of generally low milk production. Excess forage was available at all times in the pastures.

The cows on Guinea grass averaged 7,133 pounds of milk compared to 5,538 pounds for Napier grass and 5,123 pounds for Pangola grass (table 1). 
The following tabulation shows protein content of these forages, harvested by plucking to simulate grazing, as affected by season of the year. Values are averages of 36 samples taken during each 2-month period.

\begin{tabular}{|c|c|c|c|}
\hline Month & Pangola & Guinea & Napier \\
\hline March-April & 16.4 & 17.5 & 18.6 \\
\hline May-June & 14.9 & 16.8 & 16.8 \\
\hline July-August & 16.7 & 16.6 & 18.7 \\
\hline September-October & 18.3 & 18.9 & 20.0 \\
\hline November-December & 17.3 & 19.5 & 20.9 \\
\hline January-February & 18.1 & 19.8 & 20.7 \\
\hline Average & 16.8 & 18.2 & 19.3 \\
\hline
\end{tabular}

Crude-protein content of the forage was similar for all grasses, averaging $1 S .1$ percent, and varied little with season of the year.

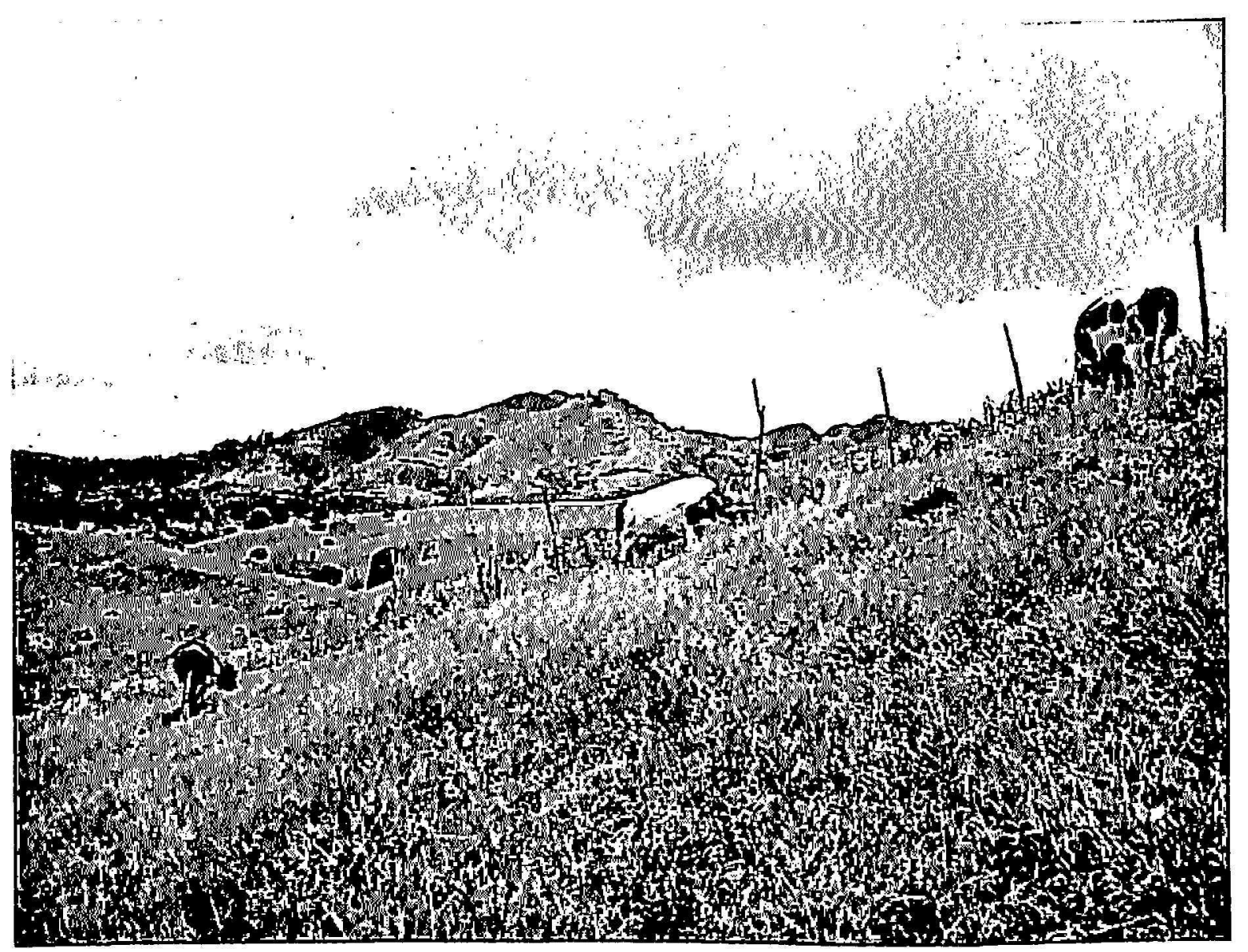

FIG. 1.-Cows fed exclusively on an all-grass ration from well fertilized, steep, tropical grass pastures at Orocovis. Eight cows in this pasture averaged 11.5 liters of milk daily over an entire lactation period while gaining slightly in weight. 
Table 2 shows how milk production of the cows on an all-grass ration decreased gradually over the lactation periods from an average of 33.4 pounds the first month to 14.2 pounds during the 8th month. The trend was similar to that of previous lactations on standard rations (fig. 2).

TABLE 2.-Monthly milk production in pounds of 8 cows on full tropical grass rations from sleep pastures, over an 8-month lactation period (approximalely April-December 1968)

\begin{tabular}{|c|c|c|c|c|c|c|c|c|c|}
\hline \multirow{2}{*}{ Month of lactation } & \multicolumn{3}{|c|}{ Guinea grass pastures } & \multicolumn{2}{|c|}{$\begin{array}{l}\text { Pangola grass } \\
\text { pastures }\end{array}$} & \multicolumn{3}{|c|}{ Napier grass pastures } & \multirow{2}{*}{ Average } \\
\hline & Cow 503 & Cow 767 & Cow 109 & Cow 422 & Cow 263 & Cow 761 & 1 Cow 822 & Cow 11 & \\
\hline & $L b$. & Lb. & $L b$. & $L b$. & Lb. & $L b$. & Lb. & $L b$. & \\
\hline 1 & $|1,042|$ & 1,171 & 1,110 & 890 & 944 & 946 & 1,059 & 843 & 1,000 \\
\hline 2 & 1,073 & 1,021 & 1,104 & 771 & 849 & 790 & 980 & 794 & 923 \\
\hline 3 & 967 & 1,040 & 1,054 & 684 & 813 & 753 & 938 & 747 & 875 \\
\hline \multirow[t]{2}{*}{4} & 941 & 1,106 & 1,058 & 650 & 711 & 619 & 883 & 781 & 844 \\
\hline & $\left|(4.5)^{*}\right|$ & (3.7) & (3.6) & $(4.2)$ & $(4.3)$ & $(4.4)$ & $(3.1)$ & $(3.7)$ & \\
\hline \multirow[t]{2}{*}{5} & 879 & 982 & 919 & 575 & 623 & 565 & 791 & 717 & 756 \\
\hline & $(3.3)$ & $(3.0)$ & $(3.6)$ & $(3.0)$ & $(4.1)$ & $(4.5)$ & $(3.8)$ & $(3.9)$ & \\
\hline \multirow[t]{2}{*}{6} & 834 & 795 & 739 & 513 & 490 & 540 & 746 & 614 & 658 \\
\hline & (3.7) & $(4.4)$ & (3.4) & (3.5) & $(4.6)$ & $(4.6)$ & $(3.6)$ & $(4.4)$ & \\
\hline \multirow[t]{2}{*}{7} & 698 & 685 & 620 & 549 & 433 & 425 & 589 & 522 & 565 \\
\hline & $(3.8)$ & $(3.1)$ & $(3.2)$ & (3.6) & $(4.0)$ & $(4.5)$ & |(3.4) & $(3.9)$ & \\
\hline \multirow[t]{2}{*}{8} & 676 & 643 & 344 & 435 & 316 & 226 & 428 & 328 & 425 \\
\hline & 7,110 & 7,443 & 6,048 & 5,067 & 5,179 & 4,864 & 6,404 & 5,346 & 6,064 \\
\hline \multirow{3}{*}{$\begin{array}{l}\text { Average daily produc- } \\
\text { tion (pounds) } \\
\text { (Liters) } \\
\text { Production during } \\
\text { previous** lacta- } \\
\text { tion (pounds) }\end{array}$} & 29.6 & 31.0 & 29.0 & 21.1 & 21.6 & 20.3 & 26.7 & 22.3 & 25.2 \\
\hline & 13.5 & 14.1 & 13.2 & 9.6 & 9.8 & 9.2 & 12.2 & 10.1 & 11.5 \\
\hline & 4,850 & 5,320 & 6,500 & 5,600 & 6,040 & 5,870 & 5,970 & 4,360 & 5,564 \\
\hline
\end{tabular}

* Numbers in parentheses show percent butter-fat content on one day of the month.

** Cows fed a ration of 4 pounds molasses daily, 1 pound of 24-percent protein concentrate per liter of milk and free choice of good quality chopped grass.

All eight cows maintained rather constant body weights throughout the lactation period (table 3 ), averaging about 1,150 pounds, which is normal for Holsteins in Puerto Rico. These data show that the cows were obtaining sufficient nutrients from the all-tropical grass ration for both milk production and maintenance.

The data suggest that cows producing up to 15 liters (33 pounds) of milk daily may obtain all their nutritional requirements from all-grass rations. 


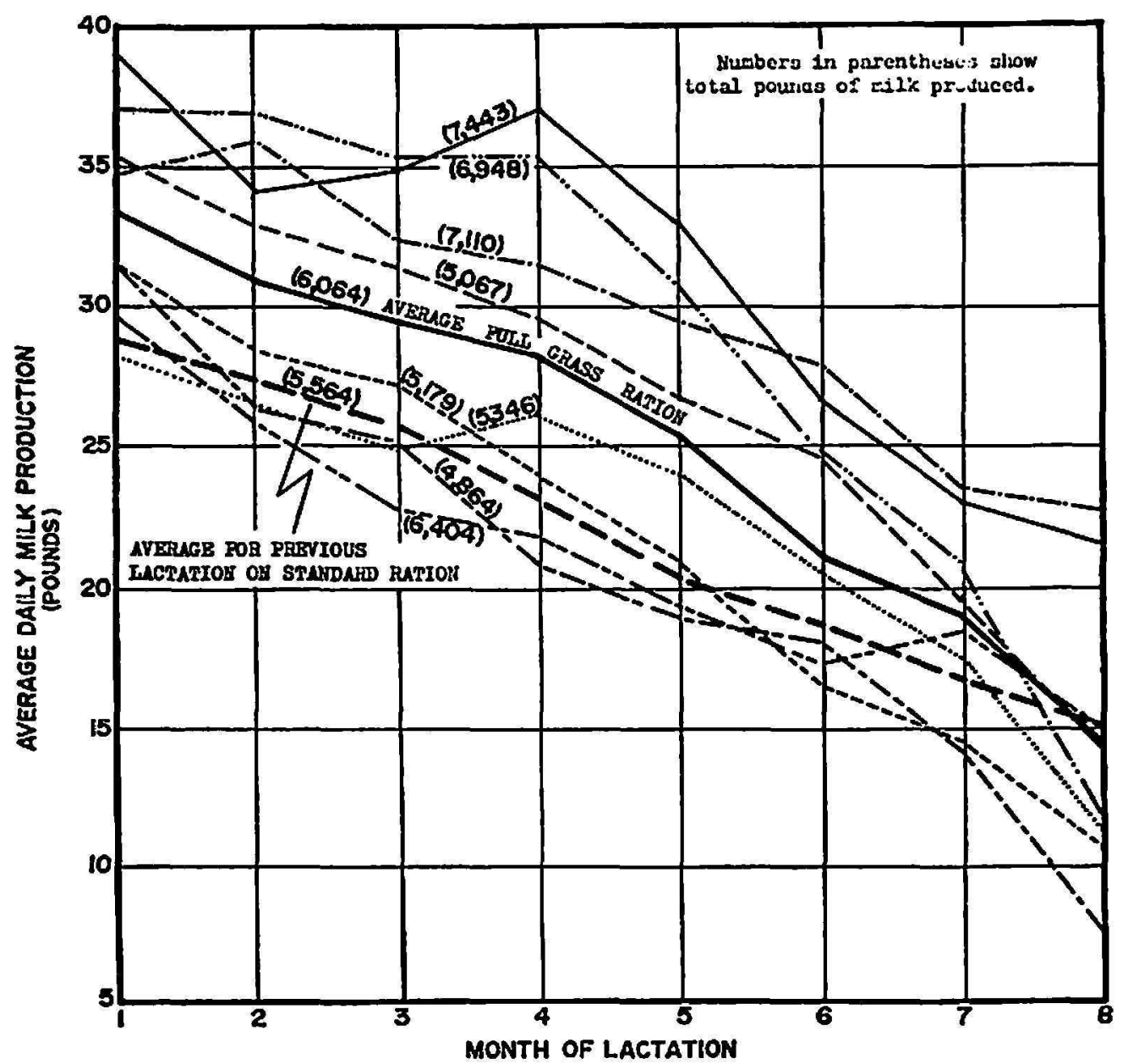

Fig. 2.-Monthly milk production of 8 cows on an all-grass ration from steep, well fertilized pastures, over an 8-month lactation period (1968).

TABLE 3.-Monthly body weights (in pounds) of 8 cows on a full tropical grass ration from steep pastures over an 8-month lactation period

\begin{tabular}{c|r|r|r|r|r|r|r|c}
\hline & \multicolumn{7}{|c}{ Body weight for month of lactation period } \\
\cline { 2 - 9 } & 1st & 2nd & 3rd & 4th & 5th & 6th & 7th & 8th \\
\hline 503 & 1,135 & 1,090 & 1,195 & 1,175 & 1,235 & 1,205 & 1,165 & 1,210 \\
109 & 1,155 & 1,080 & 1,210 & 1,140 & 1,250 & 1,245 & 1,215 & 1,220 \\
767 & 985 & 950 & 1,010 & 1,010 & 1,085 & 1,055 & 1,060 & 1,030 \\
422 & 1,035 & 995 & 960 & 1,040 & 1,040 & 1,065 & 1,055 & 1,040 \\
263 & 1,225 & 1,205 & 1,255 & 1,185 & 1,235 & 1,235 & 1,250 & 1,265 \\
761 & 1,050 & 1,045 & 1,055 & 1,025 & 1,120 & 1,140 & 1,120 & 1,120 \\
822 & 1,020 & 1,095 & 1,095 & 1,065 & 1,125 & 1,110 & 1,135 & 1,104 \\
11 & 1,145 & 1,126 & 1,155 & 1,130 & 1,180 & 1,190 & 1,210 & 1,230 \\
Average & 1,094 & 1,072 & 1,117 & 1,096 & 1,160 & 1,156 & 1,151 & 1,152 \\
\hline
\end{tabular}


Cows No. 503, 109, 822, and 767, for example, averaged 14.9, 15.8, 14.1, and 16.1 liters of milk daily, respectively, during the first 5 months of lactation (table 2) without losing weight (table 3).

Daily cost of the forage consumed by the cows on a full-grass ration was about 30 cents (Vicente-Chandler, et al. .). ${ }^{3}$ This contrasts with feed costs of 75 cents daily for similar cows fed the standard ration of 12 pounds of 24percent concentrate which cost 57 cents and 18 pounds of dry forage (about 90 pounds of green forage) which cost 18 cents.

The following tabulation shows estimated costs and profits for a 120acre dairy farm based exclusively on intensively-managed tropical pastures in the humid mountain region of Puerto Rico. Such a farm should yield a net income for management of $\$ 20,525$ yearly, or over $\$ 170$ per acre.

1. 2 milkers at $\$ 50$ per week ${ }^{1} \ldots \ldots \ldots \ldots \ldots \ldots \ldots \ldots \ldots \ldots \ldots \ldots \ldots \$ 5,200$

2. 2 laborers for managing pastures at $\$ 40$ per week (fertilizing, liming,

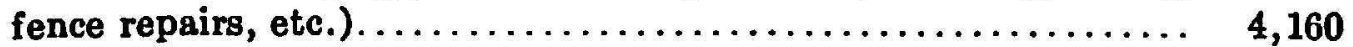

3. Fertilizer $(120 \mathrm{~T})$ and lime $(40 \mathrm{~T}) \ldots \ldots \ldots \ldots \ldots \ldots \ldots \ldots \ldots, 7,400$

4. Medicines and salt................................. 1,300

5. Light, water, transportation......................

6. Social Security, taxes and insurance................... 1,500

7. Veterinary and artificial insemination service.............. 1,800

8. Interest on land (120 acres at 600 and 8 percent)........... 5,760

9. Interest on building and equipment $(\$ 30,000$ at 8 percent $) \ldots \ldots \ldots, 2,400$

10. Interest on cattle $(\$ 40,000$ at 8 percent $) \ldots \ldots \ldots \ldots \ldots \ldots \ldots \ldots, \quad 3,200$

11. Depreciation of building (20 years) and equipment (10 years).... 2,000

12. Purchase of 6 -month-old heifers $\ldots \ldots \ldots \ldots \ldots \ldots \ldots \ldots \ldots \ldots, 3,000$

TOTAL EXPENSES ......................... $\$ 39,320$

Income -900 liters per day at $17 \notin \times \mathbf{3 6 5}$ days................ $\$ 55,845$

Sale of cattle $(20$ cows, 50 calves)............. 4,000

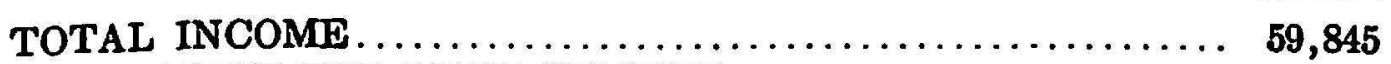

NET PROFIT FOR MANAGEMENT ................ 20,525

1 Owner helps in milking operation on milker's free day.

The data presented in this paper suggests that there is great waste in feeding concentrates at the 1-pound per liter of milk ratio used almost universally in Puerto Rico. With good pastures, only cows producing over 10 liters of milk daily should require concentrate feeds, although this must be confirmed by critical experimentation now underway.

This study also shows the vast potential for profitable milk production, which exists on thousands of acres of steep mountain lands. If each acre yields 2,000 liters of milk yearly, all the Island's present fresh-milk consumption ( 380 million liters yearly) can be produced on less than 200,000 acres of steep mountain lands. 
Some benefits of a milk industry based largely on intensively managed pastures in the Mountain Region are: 1, Reduced importations of dairy concentrate feeds which now drain $\$ 15$ million yearly from the economy; 2 , reduced imports of milk and milk products which now total $\$ 30$ million yearly; 3, reduced costs of milk production; and 4, realized potential of thousands of acres of steep mountain lands which would also be protected from erosion by the pastures.

\section{SUMMARY}

Eight cows in Puerto Rico produced an average of 6,064 pounds of milk (25.2 pounds or 11.5 liters daily) over an 8-month lactation period on an all-grass ration from steep pastures of tropical grasses. Butterfat content of the milk averaged 3.8 percent, about average for Holsteins. All cows maintained normal body weights throughout the lactation.

A 120-acre farm with all cows fed exclusively on well-fertilized and managed pastures could yield a profit of about $\$ 170$ per acre yearly.

The data suggest that the use of concentrate feeds, now almost universally fed at the rate of 1 pound per liter of milk, can be sharply reduced by using well fertilized pastures. On good pastures little or no concentrate feed should be required for the first 10 liters or so of milk produced.

\section{RESUMEN}

Ocho vacas produjeron un promedio de 6,064 libras de leche (25.2 libras u 11.5 litros diarios) durante un período de lactancia de 8 meces, alimentadas exclusivamente a base de una ración de yerbas tropicales en pastos inclinados. El contenido de grasa de la leche promedió 3.8 por ciento, que se considera normal para la raza Holstein. Durante la lactancia todas las vacas mantuvieron su peso normal.

Una finca de 120 cuerdas con vacas alimentadas exclusivamente de pastos, bien abonados y manejados podría producir una ganancia de alrededor de $\$ 170$ por cuerda al año.

Los datos sugieren que el uso del alimento concentrado, el cual se suministra generalmente a razón de 1 libra por cada litro de leche puede reducirse drásticamente si se utilizan pastos bien abonados. Cuando los pastos son buenos, no debe necesitarse alimento concentrado para los primeros 10 litros de leche que una vaca produzca. 